\title{
CONCEPTUAL APPROACHES TO STUDY THE INNOVATIVE DEVELOPMENT OF REGIONAL SOCIO-ECONOMIC SYSTEMS
}

\author{
Svitlana Fedulova ${ }^{1}$, Vitalina Komirna ${ }^{2}$ \\ Ukrainian State University of Chemical Technology, Ukraine
}

\begin{abstract}
The purpose of the paper is to find out and identify conceptual approaches to the study of the innovative development of regional socio-economic systems to take into account global requirements for global water security. Methodology. We used in our study traditional and special methods, including: historical and logical method, abstraction and analogy, and system analysis methods. Results. The article deals with the problems of innovative development of regional socio-economic systems. Conceptual approaches to the study of the innovative development of these systems are determined. Theoretical approaches to regionalization are generalized and the regional typology in world regionalism is presented. The study devotes a sufficient attention to the issues of infrastructure support for regional systems, which is a prerequisite for the functioning and development of such systems. The article focuses on the priority of research of such a component of regional infrastructure as engineering and technical infrastructure. The model of regulation of development of regional socio-economic systems on the basis of infrastructure support with the consideration of world requirements of global water security is offered. Practical implications. In recent times, the discussion on the definition of the essence of the concept of "region" is rather lively. The new paradigm of the regional economy represents the region as a variety of spatial systems of various scales. Yes, there are ongoing discussions that under the region can be understood as a group of states and small-sized administrative-territorial units. Despite the important role played by such regional systems in the economy of many countries, this topic in domestic studies is not given with enough attention. Also, in the domestic scientific schools of the regional economy, studies devoted to the problems of patterns and tendencies of the formation and development of regional systems of Ukraine, the solution of which can ensure the formation of a system of management of regional development taking into account national interests, are not sufficiently represented. Value/originality. This problem in the economic literature is investigated by many domestic scientists who devote a lot of attention to the problems of regional development management, including the following: Alymov A. (Libanova, Khvesyk, 2014), Amosha A. (Libanova, Khvesyk, 2014), Burkinsky B. (Libanova, Khvesyk, 2014), Voinarenko M. (Voinarenko, 2011), Danylyshyn B. (Danylyshyn, 2006), Dolishnii M. (Dolishnii, 2001), Vasylenko V. (Vasylenko, 2016), Dubnytskyi V. (Fokina-Mezentseva, 2012), Zakharchenko V. (Zakharchenko, 2013), Kolodynskyi S. (Kolodynskyi, 2011), Libanova E. (Libanova, Khvesyk, 2014), Liashenko V. (Liashenko, 2012), Mykula N. (Tkach, 2012), Novikova O. (Libanova, Khvesyk, 2014), Symonenko V. (Symonenko, 2016), Shevchuk L. (Shevchuk, 2011) and others. An overview of existing theoretical and methodological developments in the field of regional development has shown that significant progress has been made in this field both in foreign and domestic science. However, most of these developments have been made without taking into account the latest macroeconomic processes and trends that set the framework for the strategic planning of the sustainable development of regional systems on the basis of new spatial systems - regional socio-economic systems that can provide a new stage in the development of the old industrial economy of Ukraine.
\end{abstract}

Key words: innovation development, regionalization, regional socio-economic systems, water security, infrastructure.

JEL Classification: R11, R13, R41

\footnotetext{
Corresponding author:

${ }^{1}$ Department of Theoretical and Applied Economics, Ukrainian State University of Chemical Technology.

E-mail: sveta_fedulova@ukr.net

${ }^{2}$ Department of Theoretical and Applied Economics, Ukrainian State University of Chemical Technology.

E-mail: v.v.komirna@ukr.net
} 


\section{Introduction}

The modern economy belongs to open dynamic systems. It differs in its unpredictability because its basic element is a person and whose behaviour is difficult to predict.

Transformation processes in the development of the economy become practically continuous, which radically changes the task of man as a participant and the main coordinator of the production system. At the forefront is his or her ability to make decisions in a practically continuous transformation process, skilfully using the toolkit of positive feedback mechanisms. In modern conditions, it becomes obvious that the economic system responds (or is forced to react) to the same factors of external influence in different periods of time in different ways. The withdrawal of a significant role for a person in the development of the economic system has formed socio-economic systems, which are also in a state of dynamic equilibrium.

It should be noted that these transformational processes take place under the influence of globalization of social development, taking into account policy, economy, and culture, in the process of which the transformation of institutions of state power takes place. A part of state functions goes to a higher hierarchical level to worldwide, international-regional organizations, and transnational corporations. At the same time, there is a tendency to expand the rights of subnational territorial communities (territorial and administrative units of different levels). The global financial crisis of 2008-2009 has become a manifestation of the systemic crisis of the neoliberal model, which was based on the bank rather than production (Derhachev, Vardomsky, 2010).

In the conditions of the crisis, the formation of a multipolar model of the world order began, and regionalization of international relations has increased. The role of regional factors in social production has intensified. In the global geoeconomic system, there are trends in the formation of regional economic groups that use local ethnocultural and other features as the foundation of new development strategies (Derhachev, Vardomsky, 2010). Changing approaches to building a territorial organization of production necessitates a revision of constituent strategies of regional sustainable development.

\section{Processes of regionalization in a globalized world}

In the world of science, numerous theoretical approaches to regional development have been created. By the beginning of the 1990s, there were models of regional development within the framework of the capitalist or socialist system. In Western models, liberalization of political and economic relations was preferred, and in the Soviet-planned, closed economy in the conditions of a rigidly centralized political system. Modern conditions of globalization require the formation of new approaches. Political economic division of the world into capitalist, socialist, and developing countries also went into history. The world economy is in search for a new spatial configuration (Derhachev, Vardomsky, 2010).

Former socialist camp formed a multi-vector group of transitional (transitive) economies. The global economic space is dominated by the United States and the European Union and, at the same time, new poles are being formed. Among the developing countries, East Asian, Latin American, and near-eastern new industrialized countries (NIC) are singled out (Derhachev, Vardomsky, 2010).

In international economic relations, the benefits are given by states that are capable of creating the optimal balance between processes of globalization and regionalization (Fig. 1).

The methodological foundation for the study of regional socioeconomic systems is the theory and concept that deals with relations at the macroregional (supra-state) level, country and subregional (in-country). The grouping of existing theory and concept is presented in Fig. 2 and 3.

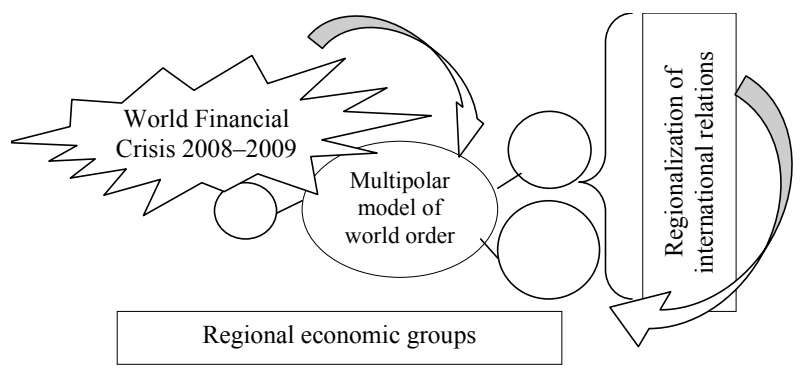

Fig. 1. Formation of processes of regionalization in a globalized world (the author's development)

Newly industrialized countries (South Korea, Taiwan, Hong Kong, Singapore) have rapidly burst into global markets. The basis of NIC's competitiveness is the ability to produce high-quality products at a low cost, high discipline, and productivity. Economic growth is facilitated by the organization of cooperation with foreign capital, including the creation of joint ventures, export industrial zones and technology parks focused on high technologies, first of all, in the field of electronics.

In the formation of a multipolar world, the role of a group of the most promising and dynamically developing economies and markets of the world will grow.

In general, since the early 1990s, Western countries have practically not increased their share in the world gross product, nor in industrial production and international trade. Japan has lost its former stability, and the United States has maintained a low growth rate (Fig. 4). The largest dynamism was marked by the East Asian countries, in the first place China and NIC. 


\begin{tabular}{|c|c|c|c|c|c|c|}
\hline & \multicolumn{6}{|c|}{ THEORETICAL APPROACHES TO REGIONALIZATION } \\
\hline \multicolumn{3}{|c|}{ Geopolitical } & Socio-economic & \multicolumn{2}{|c|}{ Political economy } & Geographic \\
\hline 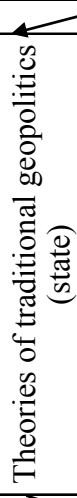 & 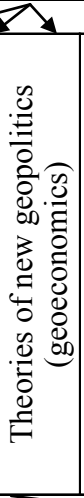 & 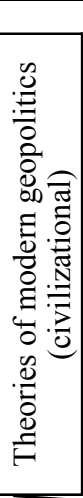 & \multicolumn{2}{|c|}{$\begin{array}{l}\frac{\downarrow}{\downarrow} \\
\text { - The theory of social } \\
\text { stratification } \\
\text { - Theories of convergence } \\
\text { - The theory of technological } \\
\text { revolutions } \\
\text { - The theory of informationalism } \\
\text { - Modern theory of growth } \\
\text { (theory of endogenous growth) } \\
\text { - The theory of economic zoning } \\
\text { and TIC } \\
\text { - The theory of regional } \\
\text { integration } \\
\text { - The theory of a regional cluster }\end{array}$} & \multicolumn{2}{|c|}{$\begin{array}{l}\text { - Protectionism } \\
\text { - The Doctrine of } \\
\text { Economic Insulation (J.M. } \\
\text { Keynes) } \\
\text { - The theory of the } \\
\text { catching-up state } \\
\text { - General regional doctrine } \\
\text { (W. Izard) } \\
\text { - Theory of the poles } \\
\text { (points) of growth }\end{array}$} \\
\hline \multicolumn{3}{|c|}{$\begin{array}{l}\text { - The theory of } \\
\text { multipolar world } \\
\text { order } \\
\text { - The theory of } \\
\text { large spaces } \\
\text { - The theory of } \\
\text { possibilism }\end{array}$} & \multicolumn{2}{|c|}{$\begin{array}{l}\text { Geo-economic theories: } \\
\text { - The doctrine of autarky of } \\
\text { large spaces } \\
\text { - The theory of zones of vital } \\
\text { interests } \\
\text { - The doctrine of the world- } \\
\text { economics } \\
\text { - The theory of world systems } \\
\text { - The theory of geoeconomic } \\
\text { world monocentrism } \\
\text { - Theory of Large } \\
\text { Multidimensional Spaces } \\
\text { - The East-South theory }\end{array}$} & \multicolumn{2}{|c|}{$\begin{array}{l}\text { - Fundamentalism } \\
\text { - Theories of } \\
\text { ethnocentrism } \\
\text { - The Gold Bullion } \\
\text { Theory } \\
\text { - The concept of } \\
\text { polycentrism and the } \\
\text { balance of } \\
\text { geostrategic forces } \\
\text { - Concept of city } \\
\text { development of } \\
\text { P. Savitsky } \\
\text { - The concept of cultural } \\
\text { and historical regions }\end{array}$} \\
\hline
\end{tabular}

Fig. 2. Generalization of theoretical approaches to regionalization (compiled by the author according to (Derhachev, Vardomsky, 2010)

Supranational regional level (regional groupings)

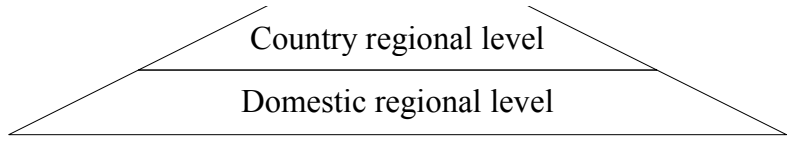

Fig. 3. The main regional levels in the globalized world space (compiled by the author according to (Derhachev, Vardomsky, 2010; Dobryanska, 2012; Global Environment Outlook, 2007; Dobryanska, 2009)

World regionalism is expressed in the regionalization of international relations, the transfer of a part of state functions to the international or subnational level. The regions, in the face of their formal and informal institutions, counteract the negative challenges of globalization and act as an independent subject of international relations; the transition from globalization to regionalization of the market and resources is planned. Many regional economic groups are created. Many developing countries see regional integration as an attempt to confront global competition. However, as the experience shows, the weaker the economy of such groups, the less effective their regionalization (Derhachev, Vardomsky, 2010).

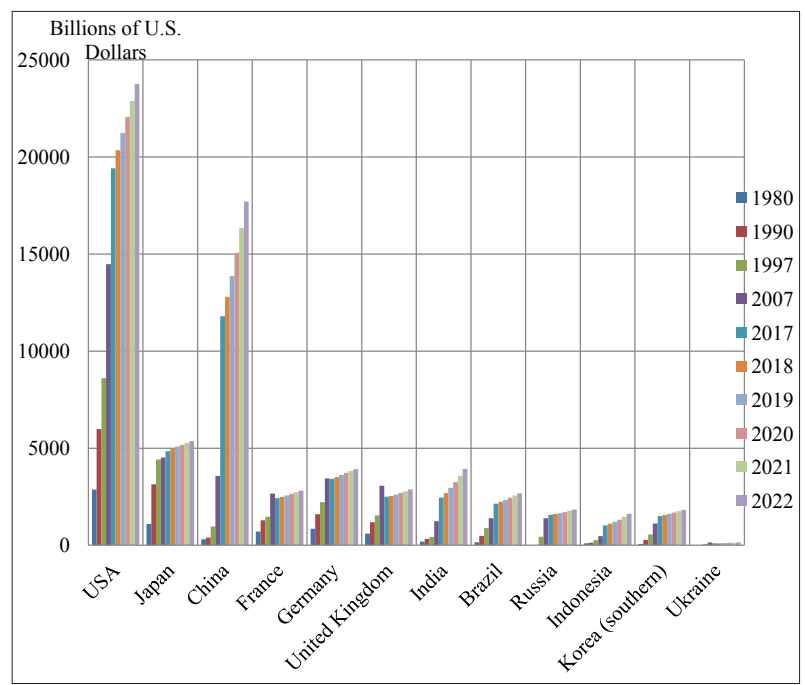

Fig. 4. Nominal GDP, billion dollars of the USA (Nominal GDP [Electronic resource], Kalabekov, 2017)

The processes of regionalization direct us to the search for ways of forming competitive regions, among which the most effective is considered a cluster approach. Recent advances in civilization development and economic thought argue that competitiveness and 
the process of clusterization are inextricably linked and mutually determined (Mikula, 2009).

In the conditions of the socialist economy, the theory of territorial-industrial complexes (TIC) was considered as an alternative to an overly centralized economy, and TIC became the objects of state planning.

Later, in the development of his scientific ideas of competitiveness, M. Porter created the theory of industrial clusters. In this theory, the logical continuation of the idea of the territorial-industrial complexes and other concepts of the concentration of production has been found. Representations of industrial clusters have been extended in the theory of a regional cluster, which means the territorial agglomeration of firms and companies operating in one or more related industries (Voinarenko, 2011).

The emergence of clusters, both industrial and regional, turned them into important institutions of the regional socio-economic system, which led to the need to study such processes in the context of the establishment of sustainable development.

The support for the cluster initiatives serves as an instrument for stimulating the economic development of depressed regions. Positive effects of cluster formation are the development of cooperation and the establishment of partnerships between companies, which in turn activates the generation of innovations, contributes to lower costs and, accordingly, creates additional competitive advantages for the regions.

Clusters are a key component of national and regional socio-economic development strategies. The necessity of such cooperation is to update the development of information technologies and other communications that weaken the role and limitations of the geographical factor in international relations. The new geography, which is under the influence of globalization, manifests itself in the regionalization and creation of large multidimensional spaces. There is a transformation of international relations, which changes the principles of construction of interstate management systems.

The modern and topical theory of large multidimensional spaces seeks to overcome the limited geographic and economic development, creating an effective geospatial at different hierarchical levels (regional grouping, country, subregion).

The creation of regions, their merging, consolidation, disintegration, and fragmentation form the essence of processes of regionalization, world and national regionalism. Regionalization, both internationally and nationally, is intimately linked to globalization.

Modern scholars highlight the creation of the following types of regions in world regionalism (see Fig. 5).

Ukraine is a European state based on the location of South-Eastern Europe between Eurasia-Russia and Central-Eastern Europe. Thus, Ukraine is a frontier country, a country with a civilizational breakdown. The borderline bipolarity is manifested in the territory of the country's geographical centre of Europe in the Carpathians and the Eurasian geopolitical pole in the Crimea. For centuries, the world's empires of the West, the East, the South, and the North formed the geopolitical outpost on such frontiers of the Eurasian steppe and the Black Sea, which provided both military parity and good-neighbourly relations among the peoples.

The multidimensional communication space of Ukraine as an independent state has three vector directions of development, namely:

- western vector;

- eastern vector;

- southern vector.

This three-vector system determines the geoeconomic code of Ukraine.

The geo-economic code is a multi-vector system of economic relations with the outside world, based on the balance of national interests, including the international and inter-corporate division of labour, which ensures the efficient functioning of the communication framework of the economy. The code is stored in the genetic memory of the multidimensional communication space of the state (region) and changes in the process of transformation of the geopolitical space (Derhachev, Vardomsky, 2010).

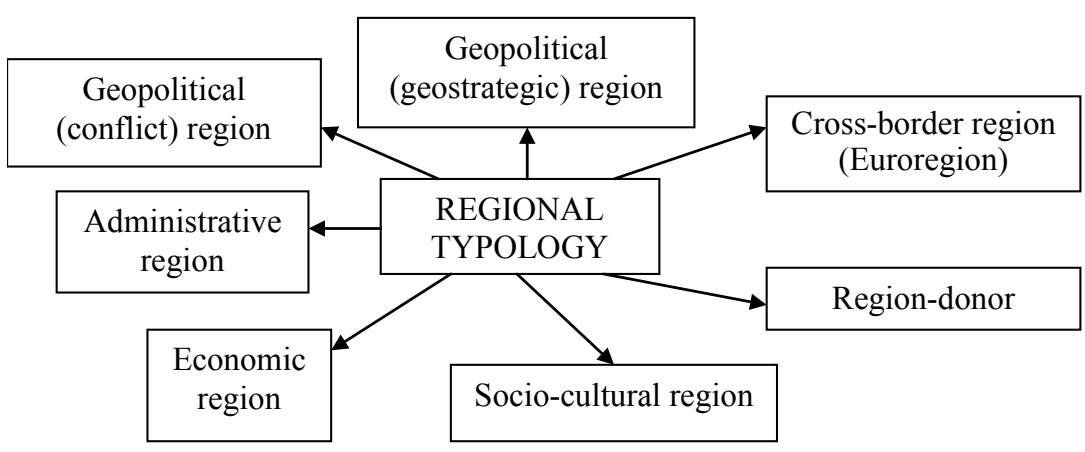

Fig. 5. Regional typology in world regionalism (compiled by the author according to (Derhachev, Vardomsky, 2010; Dobryanska, 2012; Dubnytskyi, 2014) 
Loss of one of the vectors by Ukraine will lead to the destruction of a multidimensional communication space.

It should be noted that Ukraine possesses an extremely high proportion of effective territory in the total area of the country. If we exclude two Eurasian states - Russia and Turkey, then Ukraine is the largest in terms of area and length of a European state. Compact and mastered territory of the country is characterized by the absence of extreme conditions of life. Ukraine has the largest array of chernozems.

Almost the average position of Ukraine between the North Pole and the Equator and the proximity of the warm sea create favourable comfortable conditions for people's lives and economic activity. Ukraine differs from the countries of Europe by the severity of climate (the difference between summer and winter temperatures), and a significant part of the agricultural land is located in the area of risky agriculture. Capital construction, including the construction of foundations, the thickness of the walls, the laying of water supply and heating networks in Ukraine are much more expensive, compared with other European countries, over the severity of the climate.

\section{Innovative development \\ of regional socio-economic systems}

To implement effective financing, a model for regulating the development of regional socio-economic systems is needed.

Model (French modèle, from lat. modulus - "measure, analogue, sample") - a system which research serves as a means for obtaining information about another system; the presentation of some real process, device or concept (Uemov, 1971). The number of parameters characterizing the behaviour of not only the real system but also its model is very large. To simplify the process of studying real systems, four levels of their models are distinguished, differing in the number and degree of importance of the considered properties and parameters. It is a functional, principle, structural, and parametric model.

The model of the principle of action (principal model, conceptual model) characterizes the most significant (principal) relationships and properties of the real system. Principal starting positions (methods, methods, directions, etc.) are the basis of any activity or work.

Taking into account the global requirements of global water security, we propose to regulate the development of regional socio-economic systems on the basis of providing engineering and technical infrastructure. The definition of "regional infrastructure" proposed by the author, namely, "is a fundamental factor in the life support of the regional socio-economic system (PSES), consisting of the territorial-sectoral complex of enterprises and activities that provide the needs of the population and territory in the resources, products, jobs, services of social value significance and necessary for the functioning of the system, reproduction and development for the purpose of improving the quality of life" and the world trends of economic development make it possible to give a priority to the development of engineering and technical infrastructure (on functional grounds) as the most important infrastructure of life support regional socio-economic system.

Therefore, we will concentrate on developing a basic model of regulation of the development of regional socio-economic systems on the basis of infrastructure provision (Fig. 6).

The process of regulation is a special case of the management process.

Management - is the process of influence, which is submitted to the entrance of the control object, which ensures such processes in the control object, which will ensure the achievement of a given management goal at its output.

Regulation is a separate case of management, the purpose of which is to maintain one or more outputs of the control object at a given level.

Management theory treats regulation as a management activity aimed at eliminating deviations from the given mode of operation and bringing the object of management to the desired state.

The content of regulation as a function of management consists in the redistribution of material and technical and financial resources, operational management of the course of the economic process and is based on the principles:

- rationality;

- authenticity;

- clarity;

- efficiency.

The process of regulation, as a partial management case, should, in our view, have the following algorithm for the formation of a methodology (Fig. 6).

Regulation should be based on the developed methodology. In turn, the methodology is the basis for creating a management concept. And the concept forms the appropriate management mechanism.

The basic model of regulation of the development of regional socio-economic systems on the basis of infrastructure provision determines subject and object of regulation.

Subjects of regulation are:

1. Regional state administrations.

2. Authorities of local self-government.

3. Territorial communities.

4. Non-governmental and public organizations.

2. Business.

Objects of regulation are the components of regional infrastructure.

Undoubtedly, in the regulation process, there should be direct and feedback for effective regulation. 


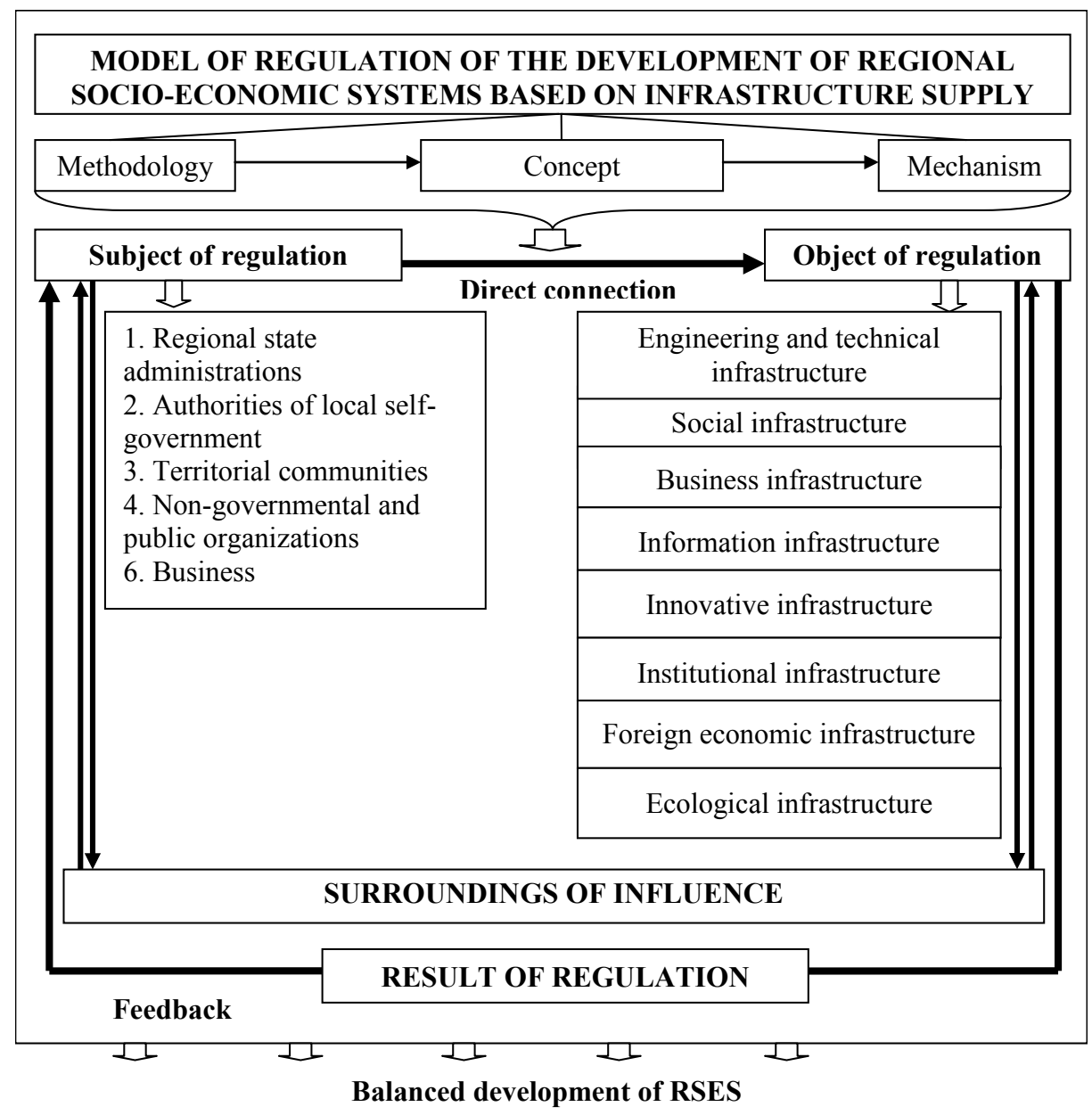

Fig. 6. Model of regulating the development of regional socio-economic systems on the basis of infrastructure provision (the author's development)

The general algorithm for developing the methodology for regulating the development of the RSES is presented in Fig. 7.

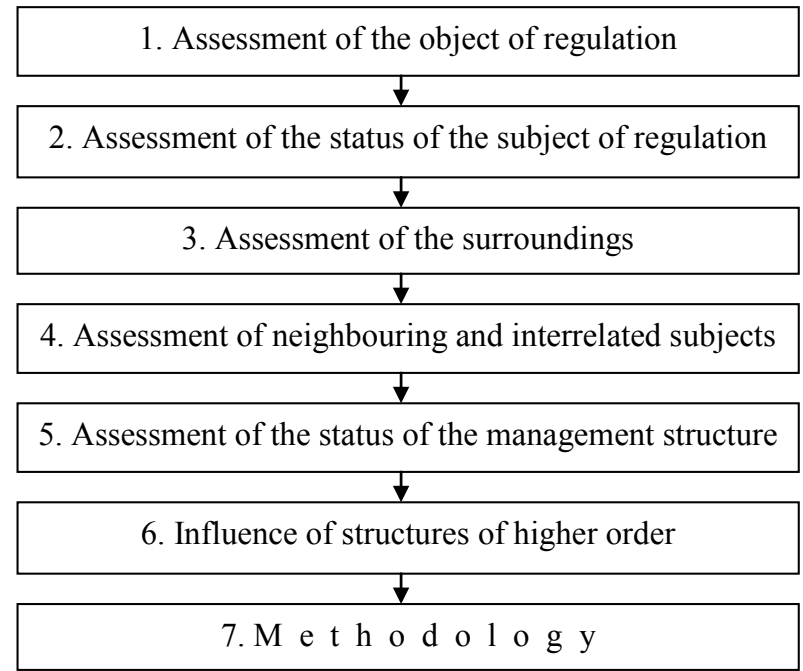

Fig. 7. The general algorithm for the formation of the methodology for regulating the development of RSES (the author's development)
The functioning of the information in management surroundings must be formalized for the formation of the concept of regulation. Such formalization can be provided by the following algorithm of action (Fig. 8).

The established practice is the prevailing current costs for environmental protection, which are 2-3 times higher than capital eco-investments. That is, entrepreneurs are limited to fulfilling the minimum, established by environmental legislation, responsibilities and avoid large-scale measures to ecologize technological processes. On the one hand, this is due to the limited financial resources, on the other - the low efficiency of environmental taxation (Vyshnevskyi, Zbarazska, Zanizdra, Chekina, 2016).

As noted in the monograph "National Model of Neoindustrial Development of Ukraine", under the general editorship of V. Vyshnevskyi, Ukraine maintains a high level of human development, that is, it has a high intellectual capital, but gradually loses its technological base of production and natural capital (Vyshnevskyi, Zbarazska, Zanizdra, Chekina, 2016).

It is noted that one of the most striking trends in the contemporary development of the world economy at the 


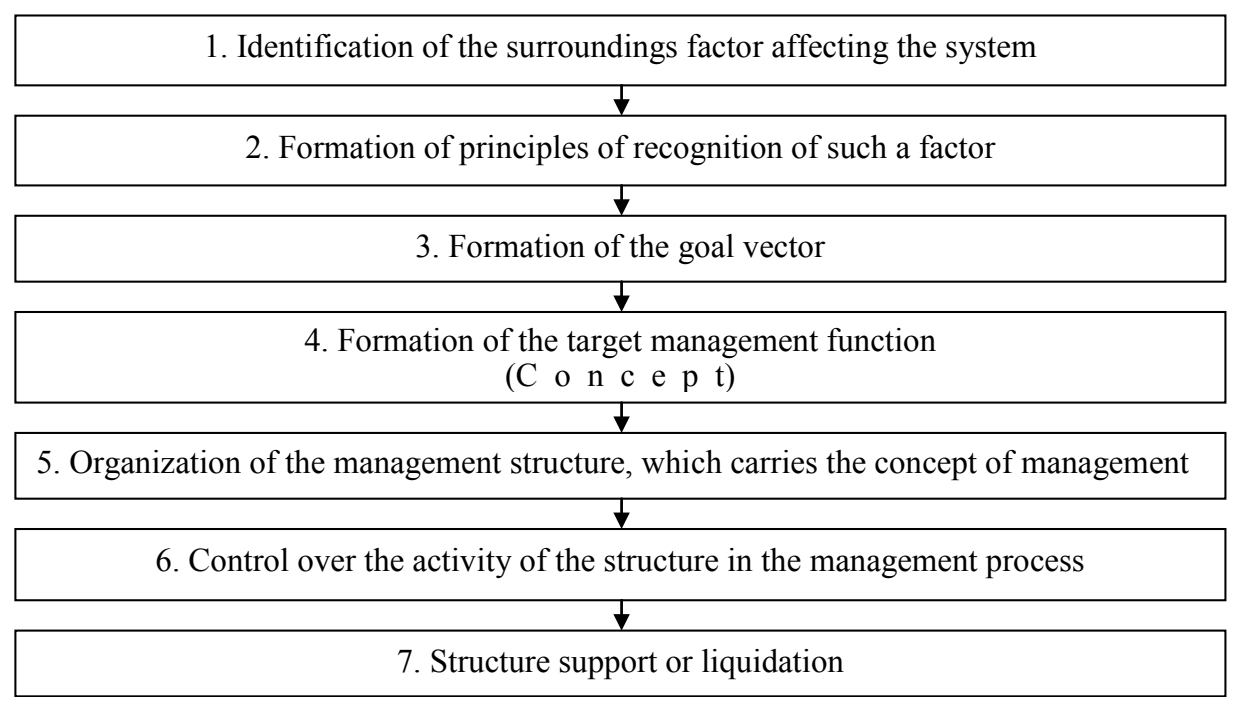

Fig. 8. Formalization of the functioning of information in the process of regulating the development of the RSES (the author's development)

beginning of the twenty-first century is a revival of active interest in the industrial sector, the purposeful formation of its progressive structure. In the world, there was a clear paradigmatic shift towards the choice of ways to develop national economies. The authors point out (Vyshnevskyi, Zbarazska, Zanizdra, Chekina, 2016) that the tasks of the post-industrial style about the priority of the information sector are no longer fulfilled, and the installation of quite tangible material goods, without control of which, the information economy, even in the most developed countries, loses (at least in part) its potential of efficiency and competitiveness. The priority has again been the industrialization, or rather, the neo-industrialization of national economies, the main purpose of which is the transition to a science-intensive "smart" leading production. It is understood as a complex of activities based on the use and coordination of information, automation of computing, software capabilities, sensory devices, computer networks, the use of leading materials and new opportunities open to the natural sciences in the fields of nanotechnology, chemistry, biology, etc. That is, such a leading production includes both new ways of manufacturing already known products (which cannot be refused), and mainly the production of new products using avant-garde technologies (Vyshnevskyi, Zbarazska, Zanizdra, Chekina, 2016).

\section{Findings}

Due to the significant differentiation of the socioeconomic development of the regions, which intensified during the financial and economic crisis of 2008, the problem of creating an effective management system has recently become even more urgent.

The entire world economy has a clear tendency to interact with mechanisms of market self-regulation and purposeful-planned development. This is manifested in the planning (regulation) at the level of business entities (business plans) and financial, budget, software and other regulation at the state level.

This circumstance is due not only to the fact that in a number of spheres of the economy (defence industry, education, science, culture, etc.), there is no direct connection between the quality of goods, factors of service production, and payment for them. The main reason - in the purely social nature of modern productive forces, in multiple and branched connections and interconnections, which makes it objectively necessary social, state regulation of the economy in the scale of the country and regions.

In a high industrial society, the productive forces represent a gigantic production and technological supersystem, in which there are powerful integration processes that reflect a significant increase in social production.

In our time, there is a change in the paradigms of regional economic development and regional policy, the search for ways to improve the management of territorial development, new forms, methods, and mechanisms of participation of regional authorities in the management of the territory.

The issue of determining the strategic priorities of regional development is extremely important for ensuring sustainable development of the state in order to reduce interregional differentiation and reduce the number of depressed regions. The study devotes sufficient attention to the issues of infrastructure support for regional systems, which is a prerequisite for the functioning and development of such systems. Ukraine has a rather outdated system of resettlement and deployment of productive forces that was created under the Soviet industrialization project. Under such 
conditions, the regional infrastructure system, as a security system, is rather worried. The article focuses on the priority of research of such a component of regional infrastructure as engineering and technical infrastructure.

In our time, there is a change in the paradigms of regional economic development and regional policy, the search for ways to improve the management of territorial development, new forms, methods, and mechanisms of participation of regional authorities in the management of the territory.

\section{Conclusions}

The issue of determining the strategic priorities of regional development is extremely important for ensuring sustainable development of the state in order to reduce interregional differentiation and reduce the number of depressed regions. The study devotes sufficient attention to the issues of infrastructure support for regional systems, which is a prerequisite for the functioning and development of such systems. Ukraine has a rather outdated system of resettlement and deployment of productive forces that was created under the Soviet industrialization project. Under such conditions, the regional infrastructure system, as a security system, is rather worried. The article focuses on the priority of research of such a component of regional infrastructure as engineering and technical infrastructure.

The author's definition of "regional infrastructure" and world business development tendencies give an opportunity to prioritize the development of engineering infrastructure (on a functional basis) as the main infrastructure for the livelihoods of the regional socio-economic system.

In today's conditions, full rehabilitation of depressed areas is not always possible; therefore, we can only talk about improving the situation in depressed areas as a necessary prerequisite for their transition to a new type of development. The constantly growing complexity and multifactorial nature of tasks of regions of Ukraine, the need to identify strategic differences in approaches to different types of regions, especially depressed, determine the relevance of improving the methodological foundations of strategic management of regional development.

\section{References:}

Danylyshyn, B. M. (2006). Sotsialnyy rozvytok Ukrayiny: suchasni transformatsiyi ta perspektyvy [Social Development in Ukraine: Contemporary Transformations and Prospects]. Cherkasy: Brama-Ukrayina [in Ukrainian].

Derhachev, V. A., Vardomsky, L. B. (2010). Rehyonovedenye [Regional studies]. M.: Yzd-vo YUNYTY-DANA [in Russia].

Dobryanska, L. O. (2009). Pidkhody do formuvannya ekolohichnoyi polityky v umovakh suchasnoyi kryzy [Approaches to the formation of environmental policy in the context of the current crisis]. Mekhanizmy rehionalnoyi polityky, № 2, 241-249 [in Ukrainian].

Dobryanska, L. O. (2012). Stratehichnyy potentsial ekolohichnoyi bezpeky: tekhnolohiya ekonomichnoho zrostannya [Strategic potential of ecological safety: technology of economic growth: monograph]. Lviv: Ukrayinskyy bestseler [in Ukrainian].

Dolishnii, M. (2001). Rynkovi mekhanizmy rehionalnoho upravlinnya [Market Mechanisms of Regional Governance]. Rehionalna ekonomika, № 1, 7-17 [in Ukrainian].

Dubnytskyi, V. I. (2014). Transformatsiya rehionalnykh hospodarskykh system pry perekhodi do staloho rozvytku: teoretychni osnovy formuvannya [Transformation of Regional Economic Systems in the Transition to Sustainable Development: Theoretical Foundations of Formation]. Cherkasy: vyd-vo Chebanenko Yu.A. [in Ukrainian].

Global Environment Outlook: environment for development. (2007). Malta: UNEP [in Europe].

Fokina-Mezentseva, K. V. (2012). Rehionalna sotsialno-ekonomichna systema: teoretychni aspekty derzhavnoho upravlinnya ta protsesu rozvytku [Regional socio-economic system: theoretical aspects of public administration and development process]. Ekonomichni innovatsiyi, № 51, 116-125 [in Ukrainian].

Kalabekov, Y. H. (2017). SSSR y strany myra v tsyfrakh. Spravochnoe yzdanye [The USSR and the countries of the world in figures. Reference book]. Moscow [in Russia].

Kolodynskyi, S. B. (2011). Restrukturyzatsiya rehionalnoho hospodarskoho kompleksu na innovatsiynykh zasadakh [Restructuring of the regional economic complex on an innovative basis: monohrafiya]. Donetsk: YuhoVostok [in Ukrainian].

Libanova, E. M., Khvesyk, M. A. (2014). Sotsialno-ekonomichnyy potentsial staloho rozvytku Ukrayiny ta yiyi rehioniv: natsionalna dopovid [Socio-economic potential of sustainable development of Ukraine and its regions: national report]. K.: DU IEPSR NAN Ukrayiny [in Ukrainian].

Liashenko, V. I. (2012). Staropromyslovi rehiony Ukrayiny: priorytety ta mekhanizmy strukturnoyi modernizatsiyi u postkryzovyy period [Old industrial regions of Ukraine: priorities and mechanisms of structural modernization in the post-crisis period]. Rehionalnyy filial Natsionalnoho instytutu stratehichnykh doslidzhen. Materialy kruhloho stolu. Donetsk [in Ukrainian].

Mikula N. Perspektyvy rozvytku transkordonnoho spivrobitnytstva Ukrayiny ta YES [Prospects for the development of cross-border cooperation between Ukraine and the EU. Electronic resource]. Retrieved from: http:/ /old.niss.gov.ua/book/Mitryaeva2009/19.pdf [in Europe]. 
Ofitsiynyy sayt Mizhnarodnoho valyutnoho fondu / Nominal GDP [Official website of the International Monetary Fund / Nominal GDP. [Electronic resource]. Retrieved from: http://www.imf.org/external/datamapper/ NGDPD@WEO/OEMDC/ADVEC/WEOWORLD/RUS/UKR [in Europe].

Shevchuk, L. T. (2011). Prostorovyy rozvytok rehionu: sotsialno-ekonomichni mozhlyvosti, ryzyky i perspektyvy [Spatial development of the region: socio-economic opportunities, risks and prospects: monograph]. NAN Ukrayiny. Instytut rehionalnykh doslidzhen. Lviv [in Ukrainian].

Symonenko, V. (20 16). Pyatyletka krutoho pyke. Ekonomycheskoe esse [Five-Year-Old Abrupt Peak. Economic essay]. K.: Dovira [in Ukrainian].

Tkach, O. V. (2012). Rehionalni prostorovo-ekonomichni systemy: suchasnyy stan ta perspektyvy rozvytku [Regional space-economic systems: current state and prospects of development: monograph]. Lviv: IRD NAN Ukrayiny [in Ukrainian].

Uemov, A. Y. (1971). Lohycheskye osnovy metoda modelyrovanyya [Logical Foundations of the Modeling Method]. M.: Mysl [in Russia].

Vasylenko,V.N.(2016).Mnohomernostparametrovrehyona:terrytoryy,systemy, prostranstva[Multidimensionality of the parameters of the region: territories, systems, spaces: monograph]. Druzhkovka: YUHO - VOSTOK [in Ukrainian].

Voinarenko, M. P. (2011). Klastery v industrialniy ekonomitsi [Clusters in the industrial economy: monograph]. Khmelnytskyy: KHNU, TOV «Triada-M» [in Ukrainian].

Vyshnevskyi, V. P., Zbarazska, L. O., Zanizdra, M. Yu., Chekina V. D. (2016). Natsionalna model neoindustrialnoho rozvytku Ukrayiny [National model of neoindustrial development of Ukraine: monogr.]. NAN Ukrayiny, In-t ekonomiky prom-sti [in Ukrainian].

Zakharchenko, V. I. (2013). Vykorystannya klasternoho pidkhodu pry formuvanni promyslovoyi polityky [Using the cluster approach in the formation of industrial policy]. Naukovyy visnyk Mizhnarodnoho humanitarnoho universytetu: Ser.: Ekonomika i menedzhment, Vyp. 6, 35-39 [in Ukrainian]. Retrieved from: http://nbuv.gov.ua/ UJRN/Nvmgu_eim_2013_6_8. 